\title{
ARGUMENTASI DALAM ARTIKEL OPINI SURAT KABAR MEDIA INDONESIA
}

\author{
Miftahul Hasanah*, Dawud \\ Universitas Negeri Malang
}

\begin{tabular}{ll}
\hline A R T I K E L & A B S T R A K \\
\cline { 3 - 3 } $\begin{array}{l}\text { Kata Kunci: } \\
\text { Argumentasi }\end{array} \begin{array}{l}\text { Penelitian ini bertujuan untuk menjelaskan argumentasi dalam artikel opini surat kabar } \\
\text { Artikel opini } \\
\text { Media Indonesia }\end{array}$ & $\begin{array}{l}\text { Media Indonesia. Jenis penelitian ini adalah kualitatif. Berdasarkan hasil analisis diperoleh } \\
\text { pendefinisian, sebab dan akibat, persamaan, pertentangan, perbandingan, kesaksian, dan } \\
\text { autoritas, (2) pola argumentasi dapat berbentuk pola sederhana dan pola kompleks. }\end{array}$ \\
\hline
\end{tabular}

\section{A RT I C LE INFO}

Keywords:

Argumentation

Opinion Article

Media Indonesia

\section{A B S T R A C T}

This research is aimed to explain argumentation in newspaper opinion articleMedia Indonesia. The research design of this study was qualitative. Based on analysis results obtained by two conclusions (1) the argumentation method can be proved with definition, cause and effect, equations, contradiction, comparison, testimony, and authority. (2) the argumentation patterns can be simple patterns and complex patterns.

(C) 2017 BIBLIOTIKA Journal. All rights reserved

\section{PENDAHULUAN}

Wacana merupakan satuan bahasa yang lengkap, di dalamnya terdapat konsep, pengertian, gagasan atau ide yang utuh. Hal ini bertujuan untuk menyampaikan informasi yang ada dipikiran penulis kepada pembaca (wacana tulis). Salah satu jenis wacana adalah wacana argumentasi. Menurut Rani, Bustanul, dan Martutik (2004:48-49), sebuah wacana dikategorikan argumentasi apabila menjabarkan alasan-alasan untuk meyakinkan pembaca agar sependapat dengan penulis terkait isu kontroversi. Jenis wacana ini menitikberatkan pada argumen atau pendapat penulis.

Penulis berusaha mempengaruhi pikiran pembaca melalui fakta-fakta yang menguatkan argumen yang diajukan. Dalam mewujudkan tujuan wacana argumentasi, penulis memerlukan cara untuk menyusun argumen dan fakta-fakta pendukung atau biasa disebut dengan argumentasi. Sejalan dengan pernyataan di atas, Keraf (2000:3) menyatakan bahwa "Argumentasi adalah suatu bentuk retorika yang berusaha untuk mempengaruhi sikap dan pendapat orang lain, agar mereka itu percaya dan akhirnya bertindak sesuai dengan apa yang diinginkan oleh penulis atau pembicara".

Menurut Keraf (2000:108), ada tujuh metode yang dapat digunakan dalam argumentasi, yaitu 1) definisi, 2) sebab dan akibat, 3) sirkumstansi 4) persamaan, 5) perbandingan, 6) pertentangan, dan 7) kesaksian dan autoritas. Penulis dapat menggunakan satu atau lebih dari satu metode dalam argumentasi. Susunan dari metode yang digunakan dalam argumentasi dapat membentuk sebuah pola. Pola yang terbentuk dapat berupa pola sederhana dan pola kompleks. Dengan menggunakan metode dan pola dalam argumentasi, pembaca lebih mudah untuk memahami pandangan penulis dan tujuan dari wacana argumentasi akan lebih mudah dicapai.

Mempengaruhi seseorang tidak hanya dilakukan ketika penutur bertemu dengan mitratutur secara langsung. Penulis dapat mempengaruhi orang lain dengan cara menuliskan hasil pemikiran dan mengirimkannya pada surat

\footnotetext{
${ }^{*}$ Corresponding author.

E-mail addresses: miftahulhasanahh@gmail.com (Miftahul Hasanah), dawud.fs@um.ac.id (Dawud)
} 
kabar. Banyak surat kabar yang telah beroperasi di Indonesia. Salah satu surat kabar yang memiliki standar yang tinggi dan dipercaya oleh pembaca adalah Media Indonesia. Terdapat berbagai tulisan dalam surat kabar Media Indonesia, salah satunya adalah artikel opini. Menurut Kuncoro (2009:32), "Artikel opini adalah tulisan lepas yang berisi opini seseorang yang mengupas tuntas satu masalah tertentu yang sifatnya aktual dan atau kontroversi dengan tujuan untuk memberitahu (informatif), mempengaruhi, dan meyakinkan atau juga bisa menghibur bagi pembacanya (bersifat recreative)".

Artikel opini merupakan salah satu jenis wacana argumentasi karena bertujuan meyakinkan pembaca bahwa pandangan penulis benar adanya. Dalam artikel opini penulis tidak hanya menyajikan argumen saja, melainkan juga pembuktian-pembuktian bahwa pendapat yang diajukan penulis benar adanya. Sama seperti wacana argumentasi yang dapat menggunakan metode argumentasi dalam menyusun argumen dan fakta, artikel opini juga dapat menggunakan metode dalam menyusun argumen dan fakta. Setiap penulis dapat menghasilkan pola yang berbeda karena metode yang digunakan berbeda. Hal inilah yang menjadikan argumentasi dalam artikel opini layak diteliti lebih mendalam.

Penelitian terdahulu yang relevan dengan penelitian ini antara lain dilakukan oleh Umami (2012), Mahfudzoh (2011), Permata (2016). Penelitian ini berkedudukan untuk melengkapi penelitian sebelumnya tentang argumentasi. Fokus penelitian sebelumnya mengarah pada karakteristik, wujud, isi, pola, teknik pengembang, gaya pengungkapan, dan tipe argumentasi. Tidak ada peneliti yang meneliti metode argumentasi. Pola dalam penelitian terdahulu menjelaskan pola yang terbentuk dari argumen, sedangkan pada penelitian ini pola yang terbentuk dari susunan metode argumentasi. Hal inilah yang menyebabkan perlunya dilakukan penelitian mengenai metode argumentasi dan pola argumentasi.

Berdasarkan paparan tersebut, penelitian ini secara umum difokuskan pada argumentasi dalam artikel opini surat kabar Media Indonesia. Adapun tujuan penelitian secara khusus, yaitu 1) menjelaskan metode argumentasi dalam artikel opini surat kabar Media Indonesia dan 2) menjelaskan pola argumentasi dalam artikel opini surat kabar Media Indonesia.

\section{METODE}

Penelitian ini menggunakan pendekatan kualitatif (Mushoffa dan Suyitno, 2017). Dengan menggunakan pendekatan kualitatif dimaksudkan agar peneliti dapat menjelaskan lebih mendalam dan lengkap tentang metode pembuktian dalam argumentasi dan pola argumentasi dalam artikel opini surat kabar Media Indonesia tanpa adanya manipulasi terhadap data penelitian. Jenis penelitian ini menggunakan analisis teks. Jenis ini dipilih karenakan penelitian ini bertujuan untuk menganalisis bahan tertulis (buku, teks, majalah, surat) berdasarkan konteknya.

Data penelitian ini berupa paragraf yang berisi metode pembuktian dalam argumentasi (pembuktian dengan pendefinisan, pembuktian dengan sebab dan akibat, pembuktian dengan sirkumstansi, pembuktian dengan persamaan, pembuktian dengan pertentangan, pembuktian dengan perbandingan, pembuktian dengan kesaksian, dan pembuktian dengan atoritas) dan pola argumentasi (pola sederhana dan pola kompleks) dalam artikel opini. Sumber data penelitian ini adalah artikel opini dalam surat kabar Media Indonesia.

Teknik-teknik pengumpulan data digunakan untuk mengumpulkan artikel opini dalam surat kabar Media Indonesia. Teknik-teknik pengumpulan data dalam penelitian ini, yaitu 1) membaca surat kabar Media Indonesia berupa opini, 2) mengklasifikasi artikel opini, 3) menandai metode pembuktian dalam argumentasi dan pola argumentasi dalam artikel opini, 4) merekam data kedalam tabel analisis 5) mengelompokkan data berdasarkan metode pembuktian dalam argumentasi dan pola argumentasi, dan 6) memberikan kode. Untuk memperoleh data yang sahih dilakukan trianggulasi data. Dalam penelitian ini, trianggulasi data dilakukan dengan cara ketekunan peneliti dan diskusi teman sejawat.

Instrumen kunci penelitian ini adalah peneliti sendiri (human instrument) karena peneliti berperan dalam menetapkan fokus penelitian, memilih sumber data, melakukan pengumpulan data, analisis data, manafsirkan data, dan membut kesimpulan atas temuannya. Selain itu, peneliti menggunakan tabel panduan kelayakan data, tabel panduan pengodean, dan tabel panduan analisis data. Tabel panduan kelayakan data digunakan sebagai pedoman penggumpulan dan reduksi data. Data yang sudah memenuhi kriteria kelayakan data, selanjutnya dianalisis dan diberi kode. Data diberikan kode sesuai klasifikasinya yang bertujuan membedakan antar satu data dengan data yang lainnya. Tabel panduan analisis data digunakan untuk menganalisis data yang didapat selama penelitian yang disusun dalam bentuk tabel.

Analisis data penelitian ini terdiri dari tiga tahapan, yaitu reduksi data, penyajian data, dan penarikan kesimpulan (Sugiyono, 2013:337). Reduksi data merupakan proses memilih data, data yang sesuai diambil, sedangkan data yang tidak sesuai. Penyajian data dapat dilakukan dalam bentuk tabel dan bagan agar data mudah dipahami. Penarikan kesimpulan dilakukan dengan merumuskan metode penmbuktian dalam argumentasi dan pola argumentasi. 


\section{HASIL DAN PEMBAHASAN}

\section{Metode Argumentasi}

Berdasarkan hasil analisis, terdapat tujuh metode argumentasi dalam artikel opini surat kabar Media Indonesia, yakni metode pembuktian dengan pendefinisian, metode pembuktian dengan sebab dan akibat, metode pembuktian dengan sirkumstansi, metode pembuktian dengan persamaan, metode pembuktian dengan perbandingan, metode pembuktian dengan pertentangan, metode pembuktian dengan kesaksian dan autoritas, serta hubungan metode argumentasi dengan artikel opini.

\section{Metode Pembuktian dengan Pendefinisian}

Pendefinisian merupakan metode argumentasi yang digunakan untuk meyakinkan pembaca dengan cara menjelaskan makna atau memberikan keterangan dari objek atau permasalahan. Penggunaan metode pendefinisian dalam artikel opini ditandai dengan memberikan pernyataan-pernyataan yang menjelaskan objek atau permasalahan yang diangkat. Dalam menggunakan metode ini penulis dapat menjelaskan definisi dari objek atau permasalahan dengan sinonim kata, etimologi, atau definisi luas.

(01) (1) PILKADA Jakarta memasuki babak 'perang kembang'. (2) Dalam pewayangan, perang kembang digambarkan perangnya kesatria dan buto cakil. (3) Dinamakan perang kembang karena merupakan kembangan dari sebuah cerita yang dibawakan seorang dalang setelah datangnya goro-goro. (4) Perang kembang akan tambah ramai dan seram setelah matinya buto cakil yang 'pethakilan' dilanjutkan dengan munculnya para raksasa yang memiliki wajah menakutkan. (5) Watak buto yakni betah buteng selalu buat kegaduhan dan onar meresahkan masyarakat. (6) Itulah yang terjadi saat ini. (7) Buto-buto politik bermunculan di pilkada Jakarta. (8) Buto bermunculan di gelanggang pilkada Jakarta karena miniatur pilihan presiden mendatang. (A012)

(02) (1) Istilah 'akhlak', berasal dari kata akhlaq, ialah bentuk jamak dari kata khuluq. (2) Kata khuluq memiliki akar yang sama dengan khalq. (3) Keduanya bermakna sifat/bentuk ciptaan yang selalu ada meski kadang dalam bentuk potensial dalam diri manusia. (4) Bedanya, jika akhalq dikaitkan dengan penciptaan yang terkait dengan penampilan fisik, khuluq terkait dengan ciptaan yang bersifat rohani. (5) Dalam salah satu doanya, Nabi Muhammad SAW pernah mengajarkan: "Ya Allah, seperti telah Kau indahkan ciptaan-fisik (khalq)-ku, indahkan juga ciptaan-rohani (khuluq)ku." (AO8)

(03) (1) TPF Kasus Munir dibentuk Presiden Susilo Bambang Yudhoyono (SBY) dengan Keppres No 111/2004. (2) TPF bertugas mencari temuan fakta atas kematian aktivis HAM Munir dan hasil kerja TPF dilaporkan kepada Presiden Susilo Bambang Yudhoyono sebagai kepala pemerintahan. (3) Dalam perspektif kearsipan, laporan TPF adalah arsip kepresidenan (presidential archives) dengan kategori 'arsip terjaga', yakni arsip negara yang berkaitan dengan keberadaan dan kelangsungan hidup bangsa dan negara yang harus dijaga keutuhan, keamanan, dan keselamatannya (Pasal 1 angka 8 UU No 43/2009 tentang Kearsipan). (4) Arsip terjaga meliputi arsip yang berkaitan dengan kependudukan, kewilayahan, kepulauan, perbatasan, perjanjian internasional, kontrak karya, dan masalah-masalah pemerintahan yang strategis. (5) Dalam konteks ini, arsip TPF Kasus Munir merupakan salah satu jenis 'arsip terjaga' karena terkait dengan masalah pemerintahan yang strategis. (6) Berdasarkan UU No 43/2009, negara secara khusus berkewajiban memberikan pelindungan dan penyelamatannya. (AO1)

Data (01) berisi bahasanPILKADA Jakarta. Penulis berusaha menunjukkan pendapat atau opini tentangMeredam Kerusuhan dengan Pemahaman Nilai Budaya. Penulis menjelaskan makna atau arti PILKADA Jakarta dengan menggunakan metode pendefinisian berupa sinonim kata. Kata lain yang disamakan makna dengan PILKADA Jakarta adalah perang kembang. Penggunaan kata perang kembang memberi arahan kepada pembaca untuk memahami PILKADA Jakarta sesuai dengan makna perang kembang. Penggunaan kata karena berfungsi sebagai penghubung alasan. Sejalan dengan temuan di atas, Keraf (2001:50) menyatakan bahwa "Definisi berupa sinonim kata adalah pembatasan pengertian sebuah kata dengan memberikan sinonim atau kata-kata yang bersamaan artinya dengan kata yang akan dijelaskan".

Data (02) berisi bahasanpendidikan karakter. Penulis berusaha menunjukkan pendapat atau opini tentangMenyoal Pendidikan Karakter.Penulis menjelaskan makna atau arti akhlak dengan menggunakan metode pendefinisian berupa etimologi atau asal-usul kata. Kata akhlak dilihat makna atau artinya menggunkaan kata akhlaq/khuluq. Penggunaan kata akhlaq/khuluq memberi arahan kepada pembaca untuk memahami akhlak sesuai dengan makna akhlaq/khuluq. Penggunaan kata ialah berfungsi sebagai penghubung sesuatu yang sama dan saling menjelaskan. Sejalan dengan temuan di atas, Keraf (2001:50) menyatakan bahwa "Definisi berupa etimologi (asal-usul kata) adalah suatu variasi lain dari definisi sinonim yang berusaha membatasi pengertian sebuah kata dengan mengikuti jejak etimologi dan arti yang asli hingga arti yang sekarang".

Data (03) berisi bahasanTPF Kasus Munir. Penulis berusaha menunjukkan pendapat atau opini tentangRaibnya Arsip TPF Kasus Munir.Penulis menjelaskan makna atau arti TPF Kasus Munir dengan menggunakan metode pendefinisian berupa definisi luas. Pada data ini sebelum dijelaskan makna TPF Kasus Munir, dipaparkan terlebih dahulu pembentuk TPF, tugas TPF, makna TPF, dan arsip terjaga. Penggunaan kata merupakan,adalah, dan yakni berfungsi menghubungkan hal yang sama dan saling menjelaskan. Sejalan dengan temuan di atas, Keraf (2000:109) 
menyatakan bahwa "Argumentasi yang mempergunakan definisi sebagai landasan geraknya, biasanya cenderung untuk mengadakan uraian panjang lebar mengenai objek kelasnya".

\section{Metode Pembuktian dengan Sebab dan Akibat}

Sebab dan akibat merupakan metode argumentasi yang digunakan untuk meyakinkan pembaca dengan cara menjelaskan hubungan penyebab dan cakupan akibat yang ditimbulkan oleh objek atau permasalahan. Penggunaan metode sebab dan akibat dalam artikel opini ditandai dengan memberikan pernyataan-pernyataan yang menghubungkan sebab dan akibat dari objek atau permasalahan. Dalam menggunakan metode ini penulis dapat menjelaskan sebab diikuti akibat dan akibat diikuti sebab.

(04) (1) Peristiwa yang bermula dari konflik politik antara penguasa dan oposisi berbuah perpecahan yang kompleks dengan lahirnya sejumlah kelompok militan seperti Al-Qaeda, Al-Nusra, dan IS. (2) Kelompok-kelompok itu punya paham dan misi yang berbeda dan mereka pun saling serang satu sama lain. (3) Buah pertempuran itu pun menimbulkan tragedi kemanusiaan yang sangat mengoyak rasa. (4) Jutaan orang terpaksa angkat kaki dari tanah air mereka. Yang tak kalah menyedihkan banyak warga tidak berdosa tewas terbantai dan teraniaya. (A011)

(05) (1) Tidak tanggung-tanggung Presiden Jokowi harus turun tangan untuk mengajak para tokoh agama dan tokohtokoh nasional ikut menurunkan tensi politik. (2) Rapat mendadak dengan Kepala Badan Intelijen Negara, Kepala Kepolisian Negara Republik Indonesia, dan Panglima TNI pun digelar untuk mengantisipasi unjuk rasa yang akan digelar ormas-ormas Islam. (3) Goro-goro politik DKI disebabkan para ormas Islam menuding Ahok, Basuki Tjahaja Purnama, gubernur nonaktif, telah menistakan agama dengan melecehkan Alquran saat berpidato di Kepulauan Seribu beberapa waktu lalu. (A012)

Data (04) berisi bahasanakibat dari perpecahan. Penulis berusaha menunjukkan pendapat atau opini tentangHarga Mahal dari Perpecahan. Penulis menjelaskan permasalahan dengan menggunakan metode sebabakibat. Pada data ini penyebab permasalahan adalah konflik politik, sedangkan akibat yang ditimbulkan adalah perpecahan. Penggunaan kata bermula yang berarti 'awal' dan kata berbuah yang berarti 'hasil' memberikan kesan kepada pembaca untuk memahami hubungan konflik politik dengan perpecahan sebagai hubungan sebab-akibat. Sejalan dengan temuan di atas, Keraf (2001:93) menyatakan bahwa "Dalam hal ini sebab bisa bertindak sebagai gagasan utama, sedangkan akibat sebagai perincian pengembangannya".

Data (05) berisi bahasanPILKADA Jakarta. Penulis berusaha menunjukkan pendapat atau opini tentangMeredam Kerusuhan dengan Pemahaman Nilai Budaya. Penulis menjelaskan permasalahan dengan menggunakan metode akibat-sebab. Pada data ini akibat permasalahan adalah Presiden Jokowi turun tangan, sedangkan penyebabnya adalah tudingan Ahok menistakan agama. Penggunaan kata tidak tanggung-tanggung yang berati 'tidak setengah-setengah' dan kata goro-goro yang berarti 'gara-gara atau sebab' memberikan kesan kepada pembaca untuk memahami hubungan Presiden Jokowi turun tangan dan tudingan Ahok menistakan agama sebagai sebuah hubungan akibat-sebab. Sejalan dengan temuan di atas, Keraf (2001:93) menyatakan bahwa "Akibat dijadikan gagasan utama sedangkan untuk memahami sepenuhnya akibat itu perlu dikemukakan sejumlah sebab sebagai perinciannya".

\section{Metode Pembuktian dengan Sirkumstansi}

Sirkumstansi merupakan metode argumentasi yang digunakan untuk menunjukkan bahwa tidak ada jalan lain selain mengikuti jalan yang diajukan penulis terhadap objek atau permasalahan. Penggunaan metode sirkumstansi dalam artikel opini ditandai dengan memberikan pernyataan-pernyataan yang menyudukan objek atau permasalahan, sehingga menggunakan jalan yang digunakan penulis. Dalam menggunakan metode ini penulis dapat menjelaskan sirkumstansi dengan solusi tunggal dan solusi prosedural.

(06) (1) Kita justru membutuhkan toleransi saat ini. (2) Dunia sudah semakin kompleks dan modern. (3) Manusia dan peradaban di dalamnya sudah semakin beragam dengan tingkat kehidupan yang lebih baik-khususnya di bidang kesehatan dan pendidikan--membuat harapan hidup semakin panjang. (4) Kesempatan semakin terbuka untuk siapa saja menjadi manusia yang berhasil, terlepas dari agama, suku, bangsa, etnik, dan gender (jenis kelamin). (5) Bumi kita yang semakin dipadati penduduk dan terancam polusi, juga pemanasan global, membutuhkan kita semua untuk bekerja keras. (6) Bagaimana mengatasi kebutuhan pangan dan energi buat 7,5 miliar penduduk (2016). (7) Di sinilah semangat toleransi diperlukan. Kita harus saling menenggang rasa dan menghargai sesama karena kita bersama-sama menghadapi masalah. (AO20)

(07) (1) Lalu bagaimana jalan keluarnya? Secara umum, kurang lebih sebaiknya pilrek mengikuti tahap sebagai berikut. (2) (1), hilangkan angka-angka kuantitatif suara menteri. .... (3) Kedua, buka informasi penjaringan bakal calon .... (4) (3), proses penjaringan bakal calon dilakukan berbasis portfolio kandidat. ... (5) (5), bila diperlukan input sivitas akademika (dosen, tenaga kependidikan, dan mahasiswa), .... (6) (7), (3) carek itu diserahkan ke pemerintah (dalam hal ini Kemenristek Dikti) untuk penentuan satu dari tiga carek tersebut menjadi rektor.(A013) 
Data (06) berisi bahasanmanfaat toleransi.Penulis berusaha menunjukkan pendapat atau opini tentangToleransi bukan Basa-basi.Penulis menunjukkan tidak ada jalan lain, selain mengikuti jalan keluar yang diajukan penulis. Pada data ini solusi yang diajukan adalah toleransi. Penggunaan kata toleransi disugestikan bahwa tidak ada jalan lain yang dapat digunakan dalam permasalahan ini. Penggunaan kata diperlukan menegaskan bahwa toleransi sangat dibutuhkan. Sejalan dengan temuan di atas, Keraf (2000:111) menyatakan bahwa "Penulis harus berusaha menyodorkan situas yang teraksa tersebut, untuk membenarkan tindakannya".

Data (07) berisi bahasankorupsi dalam pemilihan rektor.Penulis berusaha menunjukkan pendapat atau opini tentangHiruk Pikuk Pemilihan Rektor. Penulis menunjukkan tidak ada jalan lain, selain mengikuti jalan keluar yang diajukan penulis. Pada data ini solusi yang diajukan adalah mengikuti tujuh prosedur terkait pemilihan rektor. Penggunaan prosedur jalan keluar disugestikan bahwa tidak ada jalan lain lagi yang dapat digunakan dalam permasalahan ini. Penggunaan kata mengikuti menegaskan bahwa prosedur pemilihan rektor perlu untuk digunakan. Sejalan dengan temuan di atas, Keraf (2000:111) menyatakan bahwa "Sering kita menghadapi suatu persoalan, kita mengatakan bahwa 'kita terpaksa melakukan hal itu' atau 'tidak ada jalan lain kecuali itu', dan seterusnya. Inilah yang dimaksudkan dengan keadaan atau sirkumstansi".

\section{Metode Pembuktian dengan Persamaan}

Persamaan merupakan metode argumentasi yang digunakan untuk meyakinkan pembaca dengan cara menunjukkan persamaan dari objek atau permasalahan yang diangkat dengan objek lain yang berkaitan. Penggunaan metode persamaan dalam artikel opini ditandai dengan memberikan pernyataan-pernyataan yang menyetarakan kedua objek atau permasalahan.

(08) (1)Kerasnya polarisasi politik dalam demokrasi digital ini dapat kita rasakan dalam Pemilihan Presiden RI 2014 lalu. (2) Demikian juga dalam pilkada DKI yang sedang berlangsung saat ini. (3) Kasus dugaan penistaan Alquran, misalnya, bisa menjadi contoh bagaimana elite-elite politik yang berkepentingan memobilisasi massa melalui kampanye di jejaring media sosial. (4) Mereka mampu menggerakkan solidaritas berbasis identitas keagamaan itu lintas daerah bahkan lintas pulau untuk turun ke jalan menyuarakan aspirasi mereka. (AO2)

Data (08) berisi bahasanperubahan demokrasi.Penulis berusaha menunjukkan pendapat atau opini tentangDemokrasi Digital. Penulis menerangkan polarisasi dalam demokrasi digital dengan menggunakan metode persamaan.

Pada data ini objek yang disamakan dalam demokrasi digital adalah Pemilihan Presiden RI 2014 dan pilkada DKI. Kedua objek, yaitu Pemilihan Presiden RI 2014 dan kata pilkada DKI memiliki latar yang berbeda namun memiliki satu sisi yang sama, yaitu polarisasi politik. Penulis sengaja menyamakan keduanya dengan menunjukkan sisi yang sama. Sejalan dengan temuan di atas, Keraf (2001:90) menyatakan bahwa "Analogi biasanya digunakan untuk membandingkan sesuatu yang tidak atau kurang dikenal dengan sesuatu yang dikenal baik oleh umum".

\section{Metode Pembuktian dengan Perbandingan}

Perbandingan merupakan metode argumentasi yang digunakan untuk meyakinkan pembaca dengan cara menunjukkan persamaan dan perbedaan objek atau permasalahan yang diangkat dengan objek atau permasalahan lain yang berkaitan. Penggunaan metode perbandingan ditandai dengan memberikan pernyataan-pernyataan yang memebandingkan kedua objek atau permasalahan. Dalam menggunakan metode ini penulis dapat membandingkan objek atau permasalahan dengan dua objek dan lebih dari dua objek.

(09) (1) Secara umum ada perbedaan antara pandangan dunia Barat dan Timur. (2) Dalam pandangan Barat pada umumnya, kesadaran rasional--mungkin ditambah juga kesadaran estetis dan sportivitas--yang baik sudah cukup menjadi dasar bagi tumbuh-kembang karakter yang baik. (3) Bagi pandangan-dunia Timur, karakter yang baik adalah persoalan kebersihan hati. (4) Jadi, sedikit-banyak terkait dengan spiritualitas, bahkan agama. (A08)

(10) (1) Terhadap kedua orang tua atau yang kita anggap sebagai senior kita, Alquran mengingatkan kita untuk menggunakan bahasa yang mulia (qaulan kariman), '... ucapkanlah kepada mereka perkataan yang mulia' (QS alIsra'/17:23). (2) Terhadap anak-anak dan para junior, kita menggunakan bahasa yang baik dan populer (qaulan ma'rufan), '... ucapkanlah kepada mereka kata-kata yang baik' (QS al-Nisa'/4:5). ... (3) Terhadap kelompok oposisi atau kaum munafik, kita diminta menggunakan bahasa yang komunikatif (qaulan baligan), '... katakanlah kepada mereka perkataan yang berbekas pada jiwa mereka' (QS al-Nisa'/463). (4) Terhadap orang yang kasar dan jahat, tetap kita diminta menggunakan bahasa lemah lembut (qaulan layyinan), '... maka berbicaralah kamu berdua kepadanya dengan kata-kata yang lemah lembut' (QS Thaha/20:44). (5) Terhadap kelompok yang dianggap musuh pun, kita tetap diminta untuk menggunakan bahasa yang pantas (qaulan maisuran), '... katakanlah kepada mereka ucapan yang pantas' (QS al-Isra'/17:28). (A015)

Data (09) berisi bahasanpendidikan karakter. Penulis berusaha menunjukkan pendapat atau opini tentangMenyoal Pendidikan Karakter.Penulis menerangkan pandangan dengan menggunakan metode perbandingan 
berupa dua objek. Pada data ini objek yang dibandingkan dalam padangan adalah pandangan Barat dengan pandangan Timur. Penggunaan kata perbedaan memiliki arti 'sesuatu yang berbeda' menegaskan bahwa ada perbedaan antara pandangan Barat dan pandangan Timur. Kedua objek memiliki keadaan yang berbeda namun memiliki hubungan secara langsung. Sejalan dengan temuan di atas, Keraf (2001:88) menyatakan bahwa "Yang dimaksud perbandingan adalah cara dimana penulis menunjukkan kesamaan atau perbedaan antara dua orang, objek atau gagasan dengan bertolak dari segi-segi tertentu".

Data (10) berisi bahasanbahasa Ahok dalam menyinggung Alqur'an. Penulis berusaha menunjukkan pendapat atau opini tentangMemahami Bahasa Agama. Penulis menerangkan bahasa dengan menggunakan metode perbandingan berupa lebih dari dua objek. Pada data ini objek yang dibandingkan dalam bahasa adalah antara orang tua, anak-anak, kelompok oposi, orang jahat, dan musuh. Penggunaan kata terhadap yang mengandung arti 'kepada' menegaskan bahwa penulis ingin membedakan antar satu dengan yang lain karena kata ini ditujukan terhadap setiap pemakai bahasa. Sejalan dengan temuan di atas, Keraf (2001:88) menyatakan bahwa "Yang dimaksud perbandingan adalah cara dimana penulis menunjukkan kesamaan atau perbedaan antara dua orang, objek atau gagasan dengan bertolak dari segi-segi tertentu".

\section{Metode Pembuktian dengan Pertentangan}

Pertentangan merupakan metode argumentasi yang digunakan untuk meyakinkan pembaca dengan cara menentang sebuah objek atau permasalahan. Biasanya sebelum menentang terlebih dahulu dipaparkan informasi atau fakta mengenai sebuah objek atau permasalahan, selanjutnya mengkaji titik lemahnya dan memulai untuk mengeluarkan pernyataan yang bertentangan dengan objek atau permasalahan. Dalam menggunakan metode ini penulis dapat menentang objek atau permasalahan dengan antonim atau 'semestinya' .

(11) (1) Pengelolaan arsip negara harus dilihat sebagai upaya profesional dengan integritas tinggi untuk penyelamatan bahan pertanggungjawaban nasional untuk kepentingan pemerintahan dan pelayanan publik. (2) Namun, ironisnya, pengelolaan arsip negara yang tidak profesional justru telah dipertunjukkan birokrasi yang berada di ring satu lingkungan Istana Negara. (3) Kasus raibnya arsip Tim Pencari Fakta (TPF) Kasus Munir di Kementerian Sekretariat Negara (Kemensetneg), yang menjadi sorotan publik merupakan potret lemahnya pengelolaan arsip negara di lingkungan birokrasi.(AO1)

(12) (1) ISU kekisruhan pemilihan rektor (PTN) menyeruak setelah Ketua KPK Pak Agus Rahardjo menengarai ada praktik jual beli jabatan rektor. (2) Isu itu menjadi viral sangat cepat di berbagai media sosial karena persoalan itu diangkat pada saat pembahasan antikorupsi, yakni Seminar Nasional Konsolidasi Gerakan Antikorupsi Berbasis Kampus di Universitas Gadjah Mada. (3) Selain itu, tentunya masyarakat berharap banyak kepada kalangan akademisi untuk steril dari praktik-praktik yang bernuansa koruptif. (4) Betapa tidak, kampus merupakan tempat berkumpulnya para akademisi yang seharusnya tahu etika, paham pelaksanaan manajemen bersih dan baik (good governance), serta tempat mendidik generasi yang akan mengisi pembangunan di berbagai bidang. (5) Alangkah mirisnya bila di tempat penuh harapan itu terjadi praktik yang bertolak belakang dengan norma dan etika akademik. (6) Bagaimana mungkin universitas bisa membangun disiplin antikorupsi, antipungli, atau jual beli jabatan bila pucuk pimpinannya tidak bersih dari praktik seperti itu. (A013)

Data (11) berisi bahasanTPF Kasus Munir. Penulis berusaha menunjukkan pendapat atau opini tentangRaibnya Arsip TPF Kasus Munir.Penulis menerangkan pengelolahan arsip negara dengan menggunakan metode pertentangan berupa antonim atau berlawanan. Penggunaan kata upaya profesional dan kata integritas tinggi ditentang mengunakan kata tidak profesional dan kata potretlemahnya. Setiap kata yang dijadikan pembanding memiliki maksud yang berlawanan. Sejalan dengan temuan di atas, Keraf (2000:113) menyatakan bahwa "Argumentasi dengan menggunakan metode pertentangan atau kebalikan berasumsi, bahwa jika kita memperoleh keuntungan dari fakta atau situasi tertentu, maka fakta atau situasi yang bertentangan dengan fakta dan situasi tadi akan membawa bencana atau malapetaka bagi kita".

Data (12) berisi bahasankorupsi dalam pemilihan rektor.Penulis berusaha menunjukkan pendapat atau opini tentangHiruk Pikuk Pemilihan Rektor.Penulis menerangkan korupsi di kampus dengan menggunakan metode pertentangan berupa 'seharusnya' yang dilakukan objek. Pada data ini seharusnya yang dilakukan dalam kampus adalah bersih dari tindakan korupsi. Penulis berusaha menentang permasalahan atau objek dengan menunjukkan jalan yang seharusnya dilakukan objek. Sejalan dengan temuan di atas, Keraf (2000:113) menyatakan bahwa argumentasi menggunakan metode pertentangan memiliki asumsi bahwa selalu ada situasi yang berlawanan dari situasi sekarang".

\section{Metode Pembuktian dengan Kesaksian dan Autoritas}

Kesaksian merupakan metode argumentasi yang digunakan untuk meyakinkan pembaca dengan cara menjelaskan objek atau permasalahan yang diangkat sesuai dengan sudut pandang seseorang. Di sisi lain, metode autoritas digunakan untuk meyakinkan pembaca dengan cara menjelaskan objek atau permasalahan yang diangkat 
sesuai dengan pendapat dari seorang pakar atau ahli dalam bidangnya. Dalam menggunakan metode kesaksian penulis dapat menjelaskan kesaksian dari objek atau permasalahan dengan kesaksian diri sendiri atau orang lain.

(13) (1) SEMINGGU lalu saya berjumpa dengan seorang ibu berkebangsaan Suriah. (2) Wajahnya memang selalu tersenyum, tapi duka di matanya tak pernah sirna.(3) Dia mengenalkan diri sebagai Marwa. (4) Sudah empat tahun dia meninggalkan Distrik Palmyra, Provinsi Homs, Suriah. (5) Bersama tiga anaknya, dia kini tinggal di pinggiran Kota Amman, Yordania. Di Amman, Marwa menempati kamar sewa di dalam gedung kumuh yang luasnya hanya 2x3 meter. (6) Biaya sewanya 100 dinar Yordania atau setara Rp1,9 juta per bulan dengan kurs sekarang. (7) Bantuan dari Badan Pengungsi PBB (UNHCR) ialah satu-satunya sumber pemenuhan segala kebutuhan untuk bertahan hidup. (8) Setiap bulan Marwa mendapat bantuan untuk dirinya sebanyak 160 dinar, dan 100 dinar untuk (3) anaknya. (10) Angka itu tentu jauh dari cukup karena Yordania merupakan negara berbiaya hidup sangat tinggi. (11) Marwa dan (3) anaknya harus berpisah dengan Zakwan, suami dan juga ayah dari anak-anaknya. (12) Belakangan melalui kabar di media sosial, dia tahu bahwa sang suami sudah meninggal dibantai milisi propemerintah. (A011)

(14) (1) Trump membuat publik dunia khawatir karena pada saat kampanye ia banyak melontarkan pandangan kontroversial dan tidak populis. (2) Tak terkecuali Wakil Presiden RI Jusuf Kalla. (3) Ia sempat mengemukakan kekhawatirannya jika Trump terpilih sebagai presiden AS, upaya dunia selama ini untuk membangun perdamaian dan kestabilan ekonomi akan jauh dari harapan. (A016)

Data (13) berisi bahasanakibat dari perpecahan. Penulis berusaha menunjukkan pendapat atau opini tentangHarga Mahal dari Perpecahan.Penulis menunjukkan tanggapan kehidupan Marwa dengan menggunakan metode kesaksian berupa diri sendiri. Pada data ini kesaksian kehidupan Marwa ditandai dengan penggunaan kata saya yang menandakan dan membawa implikasi kesaksian. Penggunaan kata saya menunjukkan bahwa penulis terlibat langsung dalam permasalahan. Sejalan dengan temuan di atas, Keraf (2000:114) menyatakan bahwa "Kesaksian dan autoritas merupakan topik atau sumber yang bersifat dari luar".

Data (14) berisi bahasanterpilihnya Trump sebagai Presiden AS. Penulis berusaha menunjukkan pendapat atau opini tentangPragmatisme AS-Tiongkok.Penulis menunjukkan tanggapan terpilihnya Trump sebagai Presiden AS dengan menggunakan metode kesaksian berupa orang lain. Pada data ini kesaksian terpilihnya Trump sebagai Presiden AS ditandai dengan penggunaan tanggapan Wakil Preside RI Jusuf Kalla. Penggunaan kata mengemukakan yang berarti 'mengatakan' mempertegas bahwa Jusuf Kalla menanggapi permasalahan. Sejalan dengan temuan di atas, Keraf (2000:114) menyatakan bahwa "Kesaksian dan autoritas merupakan topik atau sumber yang bersifat dari luar".

Metode selanjutnya, yaitu metode autoritas. Dalam menjelaskan objek atau permasalahan penulis dapat menggunakan pendapat langsung dari ahli, buku hasil penelitian, atau hasil survei yang dapat dipertanggungjawabkan kebenarannya.

(15) (1) "TANPA arsip, suatu bangsa akan mengalami sindrom amnesia kolektif dan akan terperangkap dalam kekinian yang penuh dengan ketidakpastian. (2) Oleh karena itu, tidaklah akan terlalu keliru jika dikatakan bahwa kondisi kearsipan nasional suatu bangsa dapat dijadikan indikasi dari kekukuhan semangat kebangsaannya." (Moerdiono, mantan Mensesneg RI, 25 Maret 1996) (3) Pengelolaan arsip negara di lingkungan birokrasi sejatinya tidak dianggap remeh seperti yang umumnya ada di pikiran para birokrat kita. (AO1)

(16) (1) Dalam brain based learning theory disebutkan otak kita ketika merespons gagasan, ide atau konsep selalu dalam bentuk gambar. (2) Ambil contoh kata 'kuda' dan 'gajah', otak kita akan menerima persepsi soal kuda dan gajah tidak dalam bentuk huruf-huruf, melainkan dalam bentuk gambar. (3) Pastilah yang terbayang soal gajah bisa saja belalai, gading, kaki, dan sebagainya; sementara kuda yang terbayang ialah mulut, kaki, buntut dan bahkan suaranya. (A04)

(17) (1) Hasil survei Corruption Perception Index (CPI) 2015 menunjukkan pelayanan publik menjadi salah satu sektor yang memperlambat kenaikan skor Indonesia, termasuk juga soal penegakan hukum. (2) Jamak dipahami bahwa untuk mendapatkan pelayanan publik yang baik dan cepat selalu disertai dengan pemberian atau penerimaan sesuatu. (A07)

Data (15) berisi bahasanTPF Kasus Munir. Penulis berusaha menunjukkan pendapat atau opini tentangRaibnya Arsip TPF Kasus Munir.Penulis menunjukkan pengelolahan arsip dengan menggunakan metode autoritas berupa pendapat ahli. Pada data ini pendapat ahli yang digunakan adalah Moerdiono, mantan Mensesnag RI. Pendapatnya dianggap sebagai kata akhir karena akan keterlaluan jika pembaca masih menentang pendapat ahli. Sejalan dengan temuan di atas, Keraf (2000:115) menyatakan bahwa "Argumen dengan mempergunakan autoritas, didasarkan pada pendapat atau ucapan dari seorang yang terkenal, atau seseoraang yang diakui keahliannya".

Data (16) berisi bahasankesalahan dalam pembelajaran. Penulis berusaha menunjukkan pendapat atau opini tentang Malapraktik Pendidikan.Penulis menunjukkan respon otak manusia dengan menggunakan metode autoritas berupa pendapat buku. Pada data ini pendapat yang digunakan adalah pendapat menurut buku brain based learning theory. Penggunaan kata disebutkan yang berarti 'mengatakan' mempertegas terdapat respon otak pada buku brain 
based learning theory. Sejalan dengan temuan di atas, Keraf (2000:115) menyatakan bahwa "Pendapat atau ucapan dari seorang yang terkenal, atau seseoraang yang diakui keahliannya bisa dijadikan sebagai suatu final".

Data (17) berisi bahasanpungutan liar. Penulis berusaha menunjukkan pendapat atau opini tentangPungutan

Liar dan Penegakan Hukum.Penulis menunjukkan pelayanan publik dengan menggunakan metode autoritas berupa hasil penelitian. Pada data ini pendapat yang digunakan adalah hasil survei Corruption Perception Index (CPI) 2015. Penggunaan kata menunjukkan yang berarti 'menyatakan' mempertegas bahwa ada hasil penelitian yang berkaitan dengan pelayanan publik. Sejalan dengan temuan di atas, Keraf (2000:115) menyatakan bahwa "Argumen dengan mempergunakan autoritas, didasarkan pada pendapat atau ucapan dari seorang yang terkenal, atau seseoraang yang diakui keahliannya".

\section{Hubungan Metode Argumentasi dengan Artikel Opini}

Dalam kurikulum 2013 mata pelajaran Bahasa Indonesia diarahkan pada teks. Terdapat tiga kategori teks dalam Bahasa Indonesia, yakni teks deskripsi, teks narasi, dan teks argumentasi. Kategori yang dapat menggunankan metode mengembangkan argumentasi adalah teks yang di dalamnya terdapat bagian argumennya, yaitu kategori teks argumentasi. Salah satu teks yang ada bagian argumen di dalamnya adalah artikel opini. Dalam artikel opini penulis berusaha merebut kepercayaan pembaca agar sependapat dengan penulis.

Kompetensi Dasar yang memiliki kaitan erat dengan metode argumentasi dalam artikel opini adalah KD 3.10 dan KD 3.11. Dalam KD 3.10 berisi mengevalasi informasi, baik fakta atau opini, dalam sebuah artikel yang dibaca, sedangkan KD 3.11 berisi menganalisis kebahasaan artikel dan/atau buku ilmiah. Sebelum menjelaskan KD 3.10 dan KD 3.11, pengajar dapat menyampaikan materi tentang cara menyusun fakta atau opini dalam artikel opini sebelum memulai mengevaluasi artikel opini, yakni dengan argumentasi. Argumentasi merupakan cara penulis menyusun pendapat dan bukti-bukti atau argumen penulis yang bertujuan untuk meyakinkan pembaca atau pendengar agar sependapat dengan pandangan penulis. Ada banyak cara dalam menyusun fakta atau opini, salah satunya menggunakan metode argumentasi. Dengan mengetahui metode argumentasi, peserta didik akan lebih mudah untuk mencapai KD 3.10 dan KD 3.11 karena peserta didik telah mengetahui cara menyusun fakta atau opini dalam artikel opini, yakni dengan metode argumentasi. Peserta didik juga dapat menilai opini atau fakta yang dapat menunjang artikel opini dan opini dan fakta yang justru menjatuhkan artikel opini.

\section{Pola Argumentasi}

Berdasarkan hasil analisis, terdapat dua pola argumentasi dalam artikel opini surat kabar Media Indonesia, yaitu pola sederhana dan pola kompleks, seta hubungan pola argumentasi dengan artikel opini.

\section{Pola Sederhana}

Pola sederhana merupakan pola yang terbentuk dari gabungan metode pembuktian dalam argumentasi yang digunakan sekali atau tidak berulang dalam sebuah teks. Semua metode dapat digabung atau disatukan karena tujuannya sama, yaitu untuk meyakinkan pembaca. Pola sederhana dibagi menjadi pola gabungan dua metode pembuktian dalam argumentasi, pola gabungan tiga metode pembuktian dalam argumentasi, pola gabungan empat metode pembuktian dalam argumentasi dalam artikel opini.

(18) (1) BELUM lama ini, masalah harga gas yang dikeluhkan tinggi oleh industri pengguna gas (baik sebagai bahan baku ataupun bahan energi) telah menarik perhatian nasional hingga ke tingkat presiden ... Harga produksi gas dari lapangan-lapangan gas yang tersebar di seluruh Indonesia, baik di darat maupun di lepas pantai, bervariasi dan tidak seragam.

(2) Faktor penyebabnya tidak bersifat tunggal, tetapi relatif berkontribusi dan beresonansi,faktor pertama. ...Kedua ialah. ...Ketiga ialah sifat dan kandungan (property) dari gas itu sendiri.

(3) Ada lapangan gas yang bertekanan kuat, tetapi ada juga harus dibantu dengan injeksi. Ada lapangan gas yang kaya dengan unsur gas metana (C1), ada yang kaya dengan unsur etana, propana dan butan (C2-C4)...

(4) Biaya dan teknologi untuk memisahkan dan membuang karbon dioksida (CO2) sekitar 70\% belum ditemukan atau sangat mahal yang membuat harga gas tidak dapat terjangkau. Beberapa lapangan gas yang mengandung $40 \%$ CO2 akan jauh lebih mahal treating-nya bila dibandingkan dengan yang mengandung di bawah $10 \%$.Keempat ialah Kelima ialah jarak lokasi lapangan gas terhadap pengguna... (AO10)

Data (18) berisi bahasanharga gas yang tidak merata. Penulis berusaha menunjukkan pendapat atau opini tentangAda Apa dengan Harga Gas. Dalam menggembangkan topik atau permasalahan, penulis menggunakan pola sederhana dengan variasi gabungan dua metode, yaitu metode sebab-akibat dan metode perbandingan. Data (1), data (2), dan data (4) menggunakan metodepembuktian dengan sebab-akibat. Penggunaan metode ini memberi arahan kepada pembaca untuk memahami harga gas menggunakan metode sebab-akibat. Data (3) menggunakan metodepembuktian dengan perbandingan. Penggunaan metode ini memberi arahan kepada pembaca untuk memahami harga gas menggunakan metode perbandingan dengan variasi dua objek. Senada dengan temuan di atas, 
Roger Fowler, dkk (dalam Eriyanto, 2001:159) menyatakan bahwa "Transformasi adalah tataan tersebut bukan sesuatu yang baku, tetapi dapat diubah susunannya, dipertukarkan, dihilangkan, ditambah, dan dikombinasikan dengan yang lain dan disusun ulang". Pola metode argumentasi dengan menggunakan metode pembuktian dengan sebab-akibat dan perbandingan dapat digambarkan dengan bagan 1.1

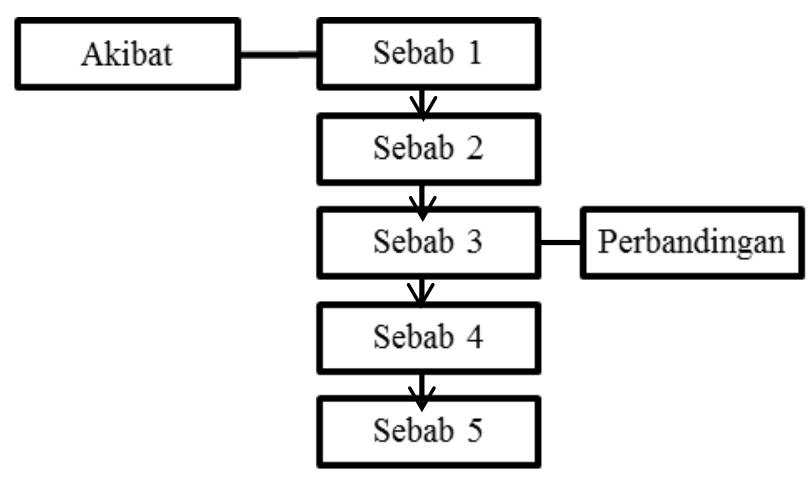

Bagan 1.1 Pola gabungan dua metode; metode pembuktian dengansebab-akibat dan metode pembuktian denganperbandingan

\section{Pola Kompleks}

Pola kompleks merupakan pola yang terbentuk dari gabungan metode pembuktian dalam argumentasi yang digunakan berulang atau lebih dari sekali dalam sebuah teks. Tidak semua metode pembuktian diulang dalam pola ini, salah satu metode pembuktian digunakan lebih dari sekali dalam teks sudah dapat dikategorikan pola kompleks. Pola kompleks dibagi menjadi pola gabungan dua metode pembuktian dalam argumentasi, pola gabungan tiga metode pembuktian dalam argumentasi, pola gabungan empat metode pembuktian dalam argumentasi, dan pola gabungan lima metode pembuktian dalam argumentasi.

(19) (1) Tak terkecuali Wakil Presiden RI Jusuf Kalla. Ia sempat mengemukakan kekhawatirannya jika Trump terpilih sebagai presiden AS, upaya dunia selama ini untuk membangun perdamaian dan kestabilan ekonomi akan jauh dari harapan....

(2) Pada 9 November 2016, sehari pascaterpilihnya Trump sebagai Presiden AS, Kepala Negara Tiongkok Xi Jinping langsung memberikan ucapan selamat. Dalam ucapannya, Jinping menyatakan harapannya, yaitu AS-Tiongkok ialah dua negara ekonomi terbesar dunia, yang punya tanggung jawab menjaga kestabilan dan perdamaian dunia.....

(3) Juru bicara Kementerian Luar Negeri Tiongkok, Lu Kang, .... Menurutnya, terlepas dari berbagai permasalahan....

(4) Beberapa pihak memprediksi hubungan Tiongkok-AS akan memanas dengan terpilihnya Trump. Namun, beberapa pakar Tiongkok menyatakan hubungan kedua negara tidak akan mengalami perubahan berarti. Hubungan Tiongkok-AS di bawah kendali Jinping-Obama yang dibangun berdasar 'negara besar kekuatan baru' selama ini memang terlihat jauh dari harmonis. Konflik dan persaingan pengaruh secara terbuka mewarnai hubungan kedua negara, terutama dalam masalah Laut China Selatan, Dalai Lama (terkait HAM), hingga tuduhan Tiongkok telah melakukan spionase siber.....(A016)

Data (4201) berisi bahasanterpilihnya Trump sebagai Presiden AS. Penulis berusaha menunjukkan pendapat atau opini tentangPragmatisme AS-Tiongkok. Dalam menggembangkan topik atau permasalahan, penulis menggunakan pola kompleks dengan variasi gabungan dua metode, yaitu metode kesaksian dan metode pertentangan. Metode yang diulang adalah metode kesaksian. Data (1), data (2), dan data (3) menggunakan metode pembuktian dengan kesaksian. Penggunaan metode ini memberi arahan kepada pembaca untuk memahami terpilihnya Trump sebagai presiden AS menggunakan metode kesaksian dengan variasi orang lain. Data (4) menggunakan metode pertentangan dengan variasi antonim. Senada dengan temuan di atas, van Dijk (dalam Eriyanto, 2001:234) menyatakan bahwa skematik adalah strategi dalam menyusun bagian-bagian dengan urutan tertentu. Pola metode argumentasi dengan menggunakan metode pembuktian dengan kesaksian dan metode pembuktian dengan pertetangan dapat digambarkan dengan bagan 1.2 


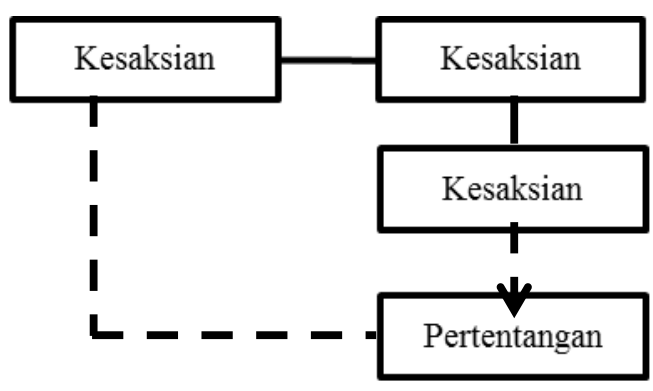

Bagan 1.2 Pola gabungan dua metode; metode pembuktian dengan kesaksian dan metode pembuktian dengan pertentangan

\section{Hubungan Metode Argumentasi dengan Artikel Opini}

Dalam kurikulum 2013 mata pelajaran Bahasa Indonesia diarahkan pada teks. Terdapat tiga kategori teks dalam Bahasa Indonesia, yakni teks deskripsi, teks narasi, dan teks argumentasi. Kategori yang dapat menggunankan pola mengembangkan argumentasi adalah teks yang di dalamnya terdapat bagian argumennya, yaitu kategori teks argumentasi. Salah satu teks yang ada bagian argumen di dalamnya adalah artikel opini. Dalam artikel opini penulis berusaha merebut kepercayaan pembaca agar sependapat dengan penulis.

Kompetensi Dasar yang memiliki kaitan erat dengan pola argumentasi dalam artikel opini adalah KD 4.10 dan KD 4.11. Dalam KD 4.10 berisi menyusun opini dalam bentuk artikel, sedangkan KD 4.11 berisi mengonstruksi sebuah artikel dengan memerhatikan fakta dan kebahasaan.Sebelum menjelaskan KD 4.10 dan KD 4.11, Pengajar dapat menyampaikan materi tentang pola argumentasi dalam artikel opini sebelum peserta didik menyusun artikel opini. Pola yang digunakan dapat berbentuk pola sederhana dan pola kompleks. Pola sederhana maksudnya metode yang digunakan dalam argumentasi tidak berulang atau digunakan hanya sekali, sehingga membentuk metode sederhana. Di sisi lain, pola kompleks artinya metode yang digunakan dalam berargumentasi berulang atau digunakan lebih dari sekali, sehingga membentuk bebrapa metode yang berulang.Dengan mengetahui pola argumentasi, peserta didik akan lebih mudah untuk mencapai KD 4.10 dan KD 4.11 karena peserta didik telah mengetahui pola apa saja yang dapat digunakan dalam artikel opini.

\section{SIMPULAN DAN SARAN}

Simpulan

Metode argumentasi yang digunakan dalam surat kabar Media Indonesia dapat berupa metode pembuktian dengan pendefinisian, metode pembuktian dengan sebab dan akibat, metode pembuktian dengan persamaan, metode pembuktian dengan pertentangan, metode pembuktian dengan perbandingan, metode pembuktian dengan kesaksian, dan metode pembuktian dengan autoritas. Metode pembuktian dengan pendefinisian dapat dinyatakan dengan bentuk pendefinisian sinonim kata, pendefinisian etimologi, dan pendefinisian luas. Metode pembuktian dengan sebab dan akibat dapat dinyatakan dengan bentuk sebab-akibat dan akibat-sebab. Metode pembuktian dengan sirkumstansi dapat dinyatakan dalam bentuk solusi tunggal dan solusi prosedural. Metode pembuktian dengan perbandingan dapat dinyatakan dengan bentuk perbandingan dua objek dan perbandingan lebih dari dua objek. Metode pembuktian dengan pertentangan dapat dinyatakan dengan bentuk antonim dan semestinya. Metode pembuktian dengan persamaan dapat dinyatakan dengan bentuk menyamakan dua objek atau permasalahan. Metode pembuktian dengan kesaksian dapat dinyatakan dengan bentuk kesaksian penulis dan kesaksian orang lain. Metode pembuktian dengan autoritas dapat dinyatakan dengan bentuk pendapat ahli, pendapat dari buku, dan pendapat survei dari sumber terpercaya.

Pola argumentasi dalam surat kabar Media Indonesia dapat digolongkan menjadi dua, yakni pola sederhana dan pola kompleks. Pola sederhana terbentuk dari gabungan metode argumentasi yang digunakan sekali atau tidak berulang dalam sebuah teks, sedangkan pola kompleks terbentuk dari gabungan metode argumentasi yang digunakan berulang atau lebih dari sekali. Pola sederhana dibagi menjadi pola gabungan dua metode argumentasi, pola gabungan tiga metode argumentasi, dan pola gabungan empat metode argumentasi. Pola kompleks dibagi menjadi pola gabungan dua metode argumentasi, pola gabungan tiga metode argumentasi, pola gabungan empat metode argumentasi, dan pola gabungan lima metode argumentasi.

\section{Saran}

Berdasarkan simpulan penelitian ini, dapat diajukan saran-saran kepada praktisi pembinaan dan pengajaran Bahasa Indonesia di sekolah, yakni penyusun buku teks dan guru Bahasa Indonesia, serta kepada peneliti argumentasi. Dalam menjelaskan, menyampaikan, dan melatihkan argumentasi hendaknya penyusun buku dan guru memperhatikan metode yang digunakan dalam argumentasi, yaitu metode pembuktian dengan pendefinisian, metode 
pembuktian dengan sebab dan akibat, metode pembuktian dengan perbandingan, metode pembuktian dengan sirkumstansi, metode pembuktian dengan pertentangan, metode pembuktian dengan persamaan, metode pembuktian dengan kesaksian dan autoritas. Penelitian ini baru dipusatkan pada penulis dalam surat kabar. Untuk memperoleh hasil kajian yang lebih menyeluruh, perlu dilakukan penelitian terhadap siswa sekolah dasar, sekolah menengah pertama, sekolah menengah atas, dan mahasiswa di perguruan tinggi dalam berargumentasi. Dengan menyertakan subjek disegala jenjang, peneliti dapat memperoleh hasil yang lebih mendalam.

\section{DAFTAR RUJUKAN}

Keraf, Gorys. 2000. Argumentasi dan Narasi. Jakarta: PT Gramedia.

Keraf, Gorys. 2001. Komposisi: Sebuah Pengantar Kemahiran Bahasa. Ende: Nusa Indah.

Kuncoro, Mudrajad. 2009. Mahir Menulis: Kiat Jitu Menulis Artikel, Opini, Kolom dan Resensi Buku. Jakarta: Erlangga.

Mushoffa, M dan Suyitno, I. (2017). Perilaku Bentuk Verba Dalam Kalimat Bahasa Indonesia Tulis Siswa Sekolah Arunsat Vitaya, Pattani, Thailand Selatan. BASINDO: Jurnal Kajian Bahasa, Sastra Indonesia, dan Pembelajarannya, Volume 1 Nomor 1 2017, pp 14-24, http://dx.doi.org/10.17977/um007v1i12017p014

Rani, Abdul, Bustanul Arifin, Martutik. 2004. Analisis Wacana: Sebuah Kajian Bahasa dalam Pemakaian. Malang: Bayumedia Publishing.

Pratama, Reca Fitry \& Dawud. 2017. Teks Tanggapan Kritis dalam Surat Kabar Harian Jawa Pos (Online). Malang: Fakultas Sastra.

Sogiyono. 2013. Metode Penelitian Pendidikan: Pendidikan Kuantitatif, Kualitatif, dan R\&D. Bandung: Alfabeta. 